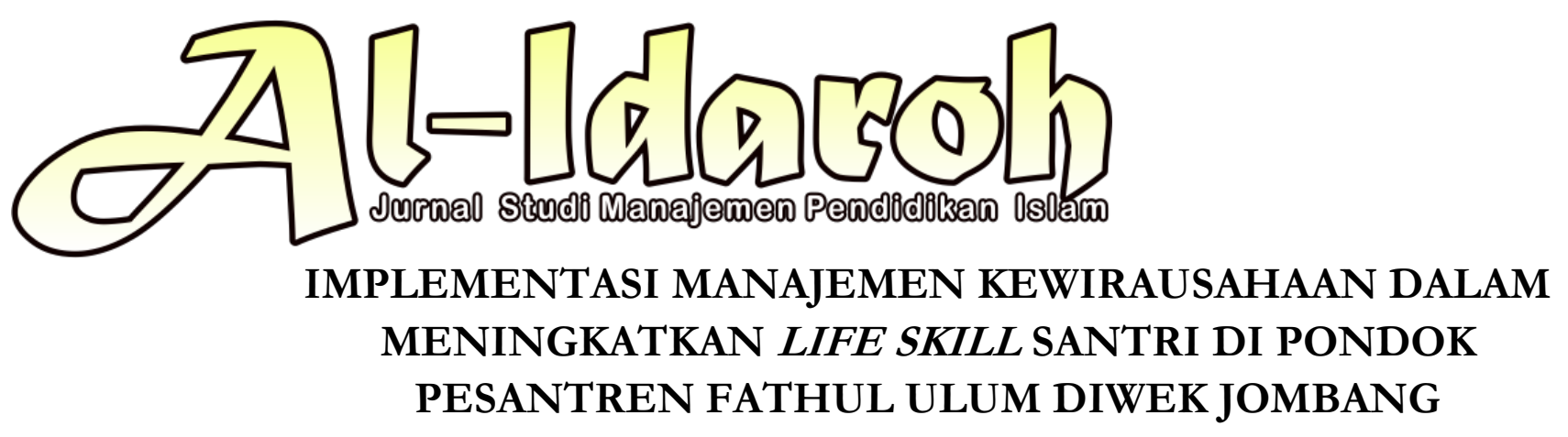

\begin{abstract}
Sunardi
Email: sunardi.ppuw@gmail.com

Prodi Manajemen Pendidikan Islam, STIT al Urwatul Wutsqo - Jombang

Sohib

Email: hujairelatholillah@gmai.com

Prodi Manajemen Pendidikan Islam STIT al Urwatul Wutsqo - Jombang

Abstract: Seeing in the era of globalization that encourages the rapid development of science and technology, of course a boarding school is required to follow these developments. Edially, pondok pesantren does not only maintain its traditional way to develop the mindset, personality and future of its students. However, it takes extra strength from all outside parties in order to further improve the quality of students, both in the religious, intellectual, and even life skills that are qualified for the students. Because in the world of education is a very basic supporting factor for the change and progress of a society. The results of research on the form of entrepreneurship in the Fathul Ulum Diwek Islamic Boarding School Jombang are in the Culinary Sector, the Agriculture Sector, the Fisheries Sector, the Printing Sector, the Sewing Sector. The Entrepreneurship Management Implementation Process in improving the life skills of the students is through planning. organizing Actuating controlling (PAOC).
\end{abstract}

Keywords: Implementation, Entrepreneurship, Life Skill

Al-Idaroh: Jurnal Studi Manajemen Pendidikan Islam

Volume 4 Nomor 2 September 2020; p-ISSN:2549-8339; e-ISSN: 2579-3683 


\section{Implementasi Manajemen Kewirausahaan dalam Meningkatkan Life Skill Santri di Pondok Pesantren Fathul Ulum Diwek Jombang}

\section{Pendahuluan}

Manajemen merupakan suatu proses di dalam menemukan transformasi baik dalam diri, maupun komunitas. Oleh sebab itu, proses manajemen yang benar adalah mengatur seseorang dari berbagai lingkungan dengan tujuan dan maksud yang jelas. dengan menerapkan empat kata kunci yang akan menjadi pengawal di dalam manajemen, empat kata kunci tersebut meliputi perencanaan (planning), mengorganisi (organizing), memimpin (guiding), mengendalikan (controlling).

Melalui empat tahapan itulah manajemen dapat bergerak, tentunya hal itu bergantung kepada tingkat kepemimpinan seorang manajer. Artinya adalah proses menejerial sebuah organisasi akan bergerak apabila para manajernya mengerti dan paham benar akan apa yang dilakukannya, begitupun dalam meningkatkan life skill yang nantinya akan sangat berpengaruh pada kehidupan di masa yang akan datang sebagaimna firman Allah:

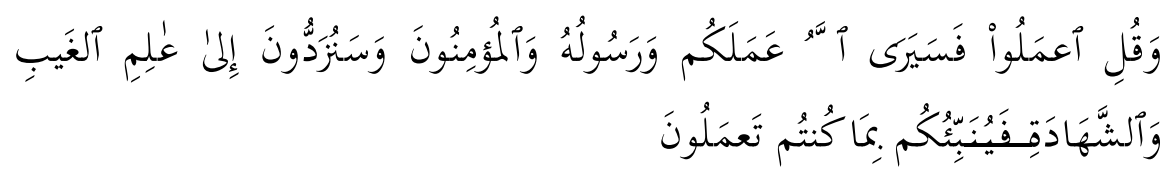

"Dan Katakanlah: "Bekerjalah kamu, maka Allah dan Rasul-Nya serta orangorang mukmin akan melihat pekerjaanmu itu, dan kamu akan dikembalikan kepada (Allah) Yang Mengetahui akan yang ghaib dan yang nyata, lalu diberitakan-Nya kepada kamu apa yang telah kamu kerjakan." (Q.S. Attaubah: 105)

Sudah saatnya dilakukan proses penginternlisasian pendidikan kewirausahaan di dunia pendidikan khususnya kepada anak didik agar memiliki karakter dan atau perilaku wirausaha yang tangguh. Diharapkan nantinya, anak didik ini akan menjadi SDM yang tangguh, jika bekerja di kantor akan menjadi tenaga kerja yang mandiri, dan tidak bekerja di kantor akan menjadi manusiayang mampu menciptakan lapangan pekerjaan, minimal bagi dirinya sendiri.

Pendidikan kewirausahaan akan memberikan peluang tumbuh dan berkembangnya potensi kreativitas dan inovasi anak. Nilai-nilai kewirausahaan akan menjadi karakteristik pesertadidik yang dapat digunakannya dalam bersosialisasi dan berinteraksi dengan lingkungannya. Pada akhirnya pribadi yang memiliki karakter kreatif, inovatif, bertanggun jawab disiplin dan konsisten akan mampu memberikan konstribusi dalam pemecahan masalah sumber daya manusia Indonesia

Pemerintah sedang merancang kerangka pendidikan yang memungkinkan peserta didik dibekali dengan kecakapan hidup (lifeskill) melalui muatan, proses pembelajaran dan aktivitas lain di sekolah. Kecakapan hidup disinitidak semata-mata terkait dengan motif 
ekonomi yang sempit, seperti ketrampilan untuk bekerja, tetapi menyangkut aspeksosial budaya, misalnya cakap berdemokrasi, ulet dan memiliki budaya belajar sepanjang hayat. Dengan demikian, pendidikan yang berorientasi kecakapan hidup pada prinsipnya adalah pendidikan yang membentuk watak dan etos. Dilihat dari kerangka ini maka iklim pendidikan di Indonesia sangat relevan dan sangat memungkinkan untuk menjadikan SDM-SDM Indonesia yang memiliki semangat dan jiwa wiraswasta ${ }^{1}$.

Pendidikan adalah suatu faktor ekternal dalam bentuk rekayasa sistematis guna meningkatkan kuantitas dan kualitas ketrampilan belajar. Prinsip dasar pendidikan adalah upayauntuk memanusiakan manusia(bumanisasi), yaitu mengembangkan potensi peserta didik agar berani dan mampu untuk meningkatkan fitrahnya sebagai khalifah di bumi, sehingga terdorong untuk memelihara diri sendiri maupun hubungannya dengan Tuhan Yang Maha Esa, masyarakat, serta lingkungannya. Untuk itu pendidikan perlu diorientasikan pada proses pemecahan masalah yang bersifat mendasar dalam hidup dan kehidupan pesertadidik.

Salah satu upaya dalam pendidikan untuk membekali peserta didik agar mampu menghadapi berbagai problem yang akan terjadi di masa yang akan datang adalah pendidikan kecakapan hidup (life skill). Pendidikan kecakapan hidup (lifes kill) memberikan kesempatan pada setiap peserta didik untuk meningkatkan potensinya dan memberikan peluang untuk memperoleh bekal keahlian/ ketrampilan yang dapat dijadikan sebagai sumber penghidupannya ${ }^{2}$.

Melihat zaman yang segalanya telah berubah yang ditandai dengan era globalisasi serta perkembangan ilmu dan teknologi, tentu sebuah pondok pesantren dituntut untuk mengikuti perkembangan tersebut. Pondok pesantren tidak tetap keukeuh dengan segala ketradisionalannya untuk mengembangkan pola pikir, kepribadian dan masa depan para santrinya. Ini dibutuhkan kekuatan ektra dari seluruh pihak luar dalam guna lebih meningkatkan kualitas santri, baik di bidang keagamaan, intelektual, bahkan terhadap life skill yang mumpuni bagi para santri. Ini mutlak harus dikembangkan oleh sebuah pesantren agar eksistensinya tetap kokh dan tak tergerus oleh zaman yang serba berorientasi pada hal yang produktif. Santri yang akan lulus dari sebuah pondok pesantren tidak akan mampu produktif bila tidak mendapatkan pendidikan yang mumpuni dari pesantren itu sendiri. Sebab pendidikan merupakan salah satu penunjang yang sangat mendasar bagi perubahan dan kemajuan sebuah masyarakat.

\footnotetext{
${ }^{1}$ Zakiah Drajat, Ilmu Pendidikan Islam (Jakarta: Bumi Aksara. 2013), 25

${ }^{2}$ Mohammad Ali, Strategi Penelitian Pendidikan. (Bandung: Angkasa, 1993), 11.
} 


\section{Implementasi Manajemen Kewirausahaan dalam Meningkatkan Life Skill Santri di Pondok Pesantren Fathul Ulum Diwek Jombang}

Problem banyaknya alumni atau lulusan pondok pesantren akan minimnya pengetahuan tentang kebutuhan dunia kerja menyebabkan semakin menambah banyaknya angka pengangguran, disamping penyerapan lulusan pendidikan formaldan nonformal juga masih rendah karena persoalan lokal yang melingkupinya, kurangnya kepercayaan di dunia kerja terhadap out put yang di keluarkan lembaga islam pesantren khususnya di dunia kerja perindustrian dan perkantoran. Sehingga out put nya termarginalkan dengan lembaga pendidikan umum. Hal itu mengakibatkan kurangnya kepercayaan diri terhadap para output lembaga pendidikan Islam pesantren. Masih banyaknya produk-produk pendidikan yang sering kali melecehkan ke hidupan dan masyarakat sekitar, misalnya sebagai petani, nelayan, pedagang, dan lain-lain. Hal ini terjadi karena anak didik lebuh banyak diintervensikan oleh praktek pendidikan model perkotaan dengan tipikal masyarakat industrial sehingga muncul ke tidak percayaan anak didik atas profesi sebagai petani atau nelayan dan memilih gaya hidup sebagai priyayi dengan fenomena keluaran pendidikan untuk menjadi Pegawai Negeri Sipil (PNS) atau minimal bekerja di perkantoran. ${ }^{3}$

Kecakapan hidup memiliki arti yang lebih luas bukan hanya sekedar keterampilan vokasional atau keterampilan untuk bekerja. kecakapan hidup (life skill) pada dasarnya adalah kemampuan seseorang untuk berjuang berani hidup (survival). Untuk itu pengembangan kecakapan hidup (life skill) pada seseorang perlu proses pendidikan dan latihan yang pada dasarnya bertujuan untuk memperoleh kemampuan dasar. Karena tanpa bekal kemampuan dasar, seseorang akan sulit untuk mengembangkan kecakapan hidupnya. Implementasi manajemen lifes kill dipondok pesantren dirasa sangat efektif untuk membantu mengatasi berbagai permasalahan yang melilit bangsa Indonesia, antaralain, besarnya angka pengangguran akibat kurang terampil. Salah satu langkah yang amat penting dalam mewujudkan masyarakat terdidik dan sejahtera untuk meningkatkan kecakapan hidup masyarakat.

Maka dari itu diperlukannya pendidikan berbasis kecakapan hidup (life skill). Kecakapan hidup (lifes kill) mempunyai makna yang lebih luas dinyatakan, tidak semata-mata berarti mempunyai kemampuan tertentu saja, namun juga harus mempunyai kemampuan dasar pendukungnya secara fungsional seperti membaca, menulis, menghitung, merumuskan, memecahkan masalah, mengolah sumber daya, bekerja dalam tim, terus belajar di tempatkerja, mempergunakan teknologi dan sebagainya ${ }^{4}$.

\footnotetext{
${ }^{3}$ Mujib Abdul, Imu Pendidikan Islam (Jakarta: Kencana Prenada Media, 2006), 5

${ }^{4}$ Departemen Agama RI, Pondok Pesantren dan Madrasab Diniyah, Pertumbuban dan Perkembangannya, (Jakarta: Ditjen Kelembagaan Agama Islam Departemen Agama RI, 2005), 11.
} 
Pondok pesantren Fathul Ulum Diwek Jombang sebagai pondok pesantren yang nota bene santrinya berasal dari berbagai daerah, sangatlah patut apabila santrinya tersebut edialnya tidak hanya disandangkan dengan ilmu agama saja, akan tetapi sebaikanya diajarkan kemampuan lainya/life skill utamanya bidang keahlian dan ketrampilan. Banyak sekali keterampilan-keterampilan di pondok pesantren namun semua itu masih minim dalam pengaturan, ini menjadi permasalahan tersendiri di kalangan pesantren, maka dengan adanya manajerial yang baik tentulah ini akan menghasilkan sesuatu yang baik karna dalam bertugas semua mengacu kepada konsep yang jelas dan tertata dengan baik. Berdasarkan paparan tersebut peneliti melakukan sebuah penelitian dengan tema "Implementasi Manajemen Kewirausahaan dalam Meningkatkan life skill Santri di Pondok Pesantren Fathul Ulum Diwek Jombang". Adapun yang menjadi konsentrasi yang akan diteliti dalam penelitan ini adalah; (1) Apa saja kewirausahaan yang dikembangkan di pondok pesantren Fathul Ulum Diwek Jombang? (2) Bagaimana bentuk implementasi manajemen kewirausahaan untuk meningkatkan life skill Santri Ulya di pondok pesantren Fathul Ulum Diwek Jombang Sementara tujuan penelitianya adalah: (1) Mendeskripsikan Kewirausahaan yang ada di PP Fathul Ulum Diwek Jombang, (2) Mendeskripsikan bentuk implementasi manajemen kewirausahaan untuk meningkatkan life skill santri Ulya di pondok pesantren Fathul Ulum Diwek Jombang.

\section{Metode Penelitian}

Penelitian yang digunakan dalam penelitian ini adalah penelitian kualitatif atau penelitian lapangan (field research) menggunakan paradigma penomenologi. Sumber primer penelitian ini meliputi pengasuh/kyai, ustad, dan santri. Teknik pengupulan data dalam penelitian ini menggunakan Interview (wawancara), observasi dan dokumentasi. Sedangkan teknis analisis data penelitian ini menggunakan redukasi data, penyajian data dan verifikasi data.

\section{Landasan Tiori}

\section{Implementasi}

Menurut Nurdin Usman dalam bukunya yang berjudul Konteks Implementasi Berbasis Kurikulum mengemukakan pendapatnya mengenai implementasi atau pelaksanaan sebagai berikut: "Implementasi adalah bermuara pada aktivitas, aksi, tindakan, atau adanya mekanisme suatu sistem. Implementasi 


\section{Implementasi Manajemen Kewirausahaan dalam Meningkatkan Life Skill Santri di Pondok Pesantren Fathul Ulum Diwek Jombang}

bukan sekedar aktivitas, tetapi suatu kegiatan yang terencana dan untuk mencapai tujuan kegiatan" 5 .

\section{Pengertian Manajemen Kewirausahaan}

Manajemen berasal dari bahasa inggris management, akar katanya adalah manage yang mengandung arti mengatur, mengurus, melaksanakan dan mengelola. Adapun Entrepreneurship atau kewirausahaan, menurut Kurat kodan Hodgetts sebagaimana dikutip oleh Manurung dalam bukunya Muh Yunus, mengatakan bahwa entrepreneur (wirausahawan), berasal dari bahasa Perancis entreprende yang berarti mengambil pekerjaan (to undertake). Wirausahawan adalah seseorang yang memiliki kemampuan menilai peluangpeluang usaha (bisnis) dan mengkombinasikan berbagai macam sumberdaya(resources)yang dibutuhkan untuk mengambil tindakan yang tepat untuk meraih keuntungan dimasa depan. ${ }^{6}$ Jadi kewirausahaan adalah seseorang yang yang memiliki kemampuan kemudian kemampuan tersebut dimanfaatkan untuk direalisasiakan dalam bentuk perbuatan dilapangan dengan tujuan untuk mendapatkan keuntungan-keuntungan yang diinginkan.

\section{Fungsi Manajemen Kewirausahaan}

Adapun fungsi-fungsi yang terdapat dalam manajemen kewirausahaan adalah sebagai berikut:

a) Perencanaan (Planning)

Perencanaan adalah proses menentukan arah yang akan ditempuh dan kegiatan-kegiatan yang diperlukan untuk mencapai tujuan yang telah ditetapkan. Dalam proses ini ditentukan tentang apa yang harus dilakukan, kapan dikerjakan/dimulai, bagaimana melakukannya, dengan cara apa hal tersebut dilaksanakan, dansiapa yang akan melakukan pekerjaan tersebut. Proses tersebut itulah yang pada akhirnya akan menghasilkan suatu rencana.

b) Pengorganisasian(Organizing)

Pengorganisasian adalah sebuah proses dimana proses tersebut bertujuan untuk mengelompokkan suatau kegiatan atau pekerjaan sehingga bisa berjalan dengan lancar. Sementara tujuannya pengorganisasian adalah agar semua tugas, fungsi tertata sesuai bidang masing-masing. Bentuk dari pengorganisasian ini bisa berbentuk struktur organisasi sesuai keinginan atau rencan yang bentuk.

c) Pelaksanaan (Actuating)

Actuating/pelaksaan ini merupakan bentuk dari perencanaan yang telah dibuat sehingga dibuktitikan dengan perbuatan/pelaksaan. Sebgai pemimpin edialnya berupaya untuk selalu

${ }^{5}$ Moh. Uzer Usman, Menjadi Guru Profesional (Bandung: PT Remaja Rosdakarya, 2008), 11

${ }^{6}$ Muchlas Samani, Kecakapan Hidup Melalui Pendekatan Pendidikan Berbasis Luas, (Team Broad Based Education LPM Unesa.Surabaya: Swa Bina Qualita Indonesia, 2008), 16. 
menggerakkan bawahannya agar melaksanakan tugas dan fungsinya sesuai yang telah direncanakan. Bentuk dari penggerakan tersebut bisa berbentuk memberi perintah, memberi petunjuk dan memotivasi, pelaksanaan pekerjaan dilakukan dengan berpedoman pada rencana yang telah disusun

d) Pengawasan (Controlling)

Controlling/pengawasan ini merupakan proses penilaian terhadap suatu pekerjaan agar mengetahui sejauhmana upaya-upaya yang telah dilakukan apakah sudah tercapai sesuai dengan tarjet atau tidak. Sehingga jika menemukan suatu kendala maka seorang pemimpin berupaya menentukan tindakan-tindakan dalam menyelesaikan masalah.

\section{Pengertian Life Skill}

Life Skil latau kecakapan hidup didefinisikan berbeda-beda, namun esensi pengertiannya sama. Brolin mendifinisikan kecakapan hidup sebaga ikontinum pengetahuan dan kemampuan yang diperlukan oleh seseorang untuk berfungsi secara independen dalam kehidupan. Sedangkan menurut Malik Fajar mendifinisikan kecakapan hidup sebagai kecakapan untuk kerja selain kecakapan yang berorientasi pada jalur akademik7 . Tim Broad-Based Educatio, mendifinikan bahw alife skill adalah kecakapan yang dimiliki seseorang untuk mau dan berani menghadapi problema hidup dan kehidupan secara wajar tanpa merasa tertekan, kemudian secara proaktif dan kreatif mencariserta menemukan situasi sehingga akhirnya mampu mengatasinya.

\section{Hasil Penelitian}

\section{Bentuk-bentuk kewirausahaan di Pondok Pesantren Fathul Ulum Diwek Jombang}

\section{a. Bidang Tata Boga}

Bidang usaha yang sudah dikembangkanya itu Lele Krispi, Telur Asin. Bidang usaha ini merupakan bidang usaha yang paling banyak menyerap tenagakerja dan banyak diminati karena selain memberi peluang penghasilan yang besar juga lebih berorientasi pada hasil. Sebagimana hasil Wawancara dengan Pengasuh Pondok Pesantren Fathul Ulum: "Kewirausahaan dan life skill yang ada di Pondok Pesantren Fathul Ulum Fathul Ulum sementara ini ada peternakan, penjahitan, perikanan dan perternakan, percetakan, pengelasan namun yang sekarang berkembang yaitu dibidang perikanan terutama lele, karena mudah sekali dalam pengelolaaan lele.”

7 Slamet, Pendidikan Kecakapan Hidup; Konsep Dasar.Jurnal Pendidikan dan Kebudayaan no. 037 tahun VIII Juli 2002), 144. 


\section{Implementasi Manajemen Kewirausahaan dalam Meningkatkan Life Skill Santri di Pondok Pesantren Fathul Ulum Diwek Jombang}

Kegiatan kewirausahaan ini dilaksanakan setiap hari dan santri-santri didampingi oleh Kepala bidang atau yang di tunjuk oleh kepala bidang. Mereka mengikuti Life Skill selama satu jam dari pukul 13.00 sampai pukul 14.00 Halini senada dengan hasil wawancara dengan santri kelas Ulya, II "saya mengikuti kegiatan kewirausahaan mulai masuk kelas ulya yang sering saya ikuti yaitu Perikanan, untuk waktunya telah terjadwal biasanya setelah dzuhuru pukul satu sampai pukul dua atau di waktu libur ngaji diisi dengn kewirausahaan."

b. Bidang Peternakan

Usaha bidang peternakan penuhdengan dinamika danpenuh tantangan sehingga perlu penanganan khusus, karena yang dihadapi adalah makhluk hidup yang bergerak dan tentu mempunyai kekhasan masing-masing. Karenaitu, perlu kesiapan mental dan ketelatenan dalam pemeliaraan. Pondok Pesantren Fathul Ulum ini membekali santrinya dengan memelihara kambing, ayam, dan Bebek Pondok pesantren menyediakan lahan atau kandang dan pakan. Santri yang bertugas memelihara hewan ternak dipondok pesantren Fathul Ulumini adalah santri-santri putra yang masih tarbiyyah.

Sebagaimana hasil wawancara dengan Pengasuh. "dalam usaha bidang peternakan saya memillih hewan ternak kambing, ayam dan bebek karena sudah umum di masyarakatat, sehingga santri yang keluar bisa menyebarkan ilmu tentang peternakan dan juga yang kita gunakan sudah mulai bagaimna santri tidak terlalu memakan waktu banyak dalam menjalankannya.

c. Bidang Perikanan

Usaha perikanan adalah salah satu jenis usaha yang dikembangkan di pondok pesantren Fathul Ulum, jenis ikan yang dibudidayakan dipesantren ini adalah ikan patin dan lele. Membudidayakan ikan di Pondok Pesantren Fathul Ulum merupakan kewirausahaan yang berkaitan dengan life skill santri yang praktek langsung di kolam budidaya dengan bimbingan intensif langsung oleh Ustadz. Usaha perikanan ini amat potensial sekali baik yang dilaut maupun didarat. Sebagaimana hasil wawancara dengan Kepala Bidang Perikanan. "perikanan yang dibudidayakan di pondok pesantren ini yaitu patin danlele jika sudah bisa dipanen ikan dijual dan hasilnya untuk pondok. Kewirausahaan ini butuh ketelatenan dan kesabaran dalam merawatnya. Tugasnya memberi pakan dan membersihkan kolam.”

d. Bidang Pertanian

Bidang pertanian merupakan salah satu program pengalaman santri dalam mengelola ladang pertanian. Setiap hari sesuai jadwal yang telah diberikan pondok. 
Parasantri mengikuti kegiatan kewirausahaan padalahan pertanian yang dimiliki pondok pesantren. Program kegiatan bidang pertanian mampu memberikan pemahaman kepada santri secara general terhadap satu bidang komoditas usaha. Para santri diajarkan cara menanam dan perawatan. Sebagaimana yang disampaiakan oleh Pengasuh. "Bidang pertanianini diadakan karena melihat rata-rata santri yang mondok kesini adlah keluarga dari kalangan petani, dengan adanya bidang pertanian ini dengan harapan santri bisa mngembangkan pertaniann ini dengn modern dengan menggunakan teknologi sehinga waktunya tidak tersibukan dengan pertaniann saja tapi bisa untuk kemanfaatan dakwah keagamaan.”

Hal ini dilakukan tidak hanya sekedar untuk memperoleh keuntungan finansial tetapi sebagai media dalam mengembangkan skill agar berjiwa wirausaha dan menjadi pembelajaran mental bagi santri.

e. Bidang Percetakan

Bidang percetakan merupakan salah satu kewirausahaan yang ada di PP Fathul Ulum, pengadaan kewirausahan ini berawal dari minat santru yang mempunyai kompetensi dibidang percetakan dan kemauan sendri sehingga bidang ini bisa di wujudkan. Hal ini diungkapkan oleh pengasuh. "Adanya percetakan ini karena berawal dari salah satu santri yang sowan ke ndalem, dengan mengajukan keinginannya untuk menekuni di bidang percetakan"

f. Bidang Penjahitan

Bidang penjahitan merupakan salah satu kewirausahaan yang ada di Pondok Pesantren Fathul Ulum, pengadaan kewirausahan ini untuk penunjang santri yang ingin mengikuti program penjahitan, karna untuk bidang jahit ini tergolong bidang yang sulit dalam pembelajarannya karna diperluan keteltenan dan ketekunn dalam mendalaminnya, tidak hanya itu adanya penjahitan melengkapi kewirausahaan yang ada di Pondok Pesanren Fathul Ulum yang nantinya mereka akan di bagi dan diberi pekerjaan terutama pembuatan seragam pondok khususnya yang ada di Pondok Pesantren Fathul Ulum umumnya kpada Pondok yang lainnya. Sebagaimna yang disampaikan oleh Pengasuh. "Life skill ini merupakan yang paling sulit karena tidak hanya kemampuan tapi ketekuan yang dimilii santri, dan nantnnya program kedepannya yaitu mereka mampu meproduksi baju dari sini (PPFU).”

\section{Implementasi Manajemen dalam meningkatkan Kewirausahaan di Ponpes}

\section{Fathul ulum}

Al-Idaroh - ISSN: 2549-8339 EISSN: 2579-3683| 218 
a. Tahapan pertama Pengasuh mengintruksikan kepada Ketua BUMP, Kemudian Ketua BUMP (Badan Usaha Milik Pondok) menginformasikan Manajerial atau tata kelola kewirausahaan. Hal ini di dasarkan pada pernyataan Kepala Bidang Perikanan "Pas saya pertama masuk sebelum saya menjadi kepala di bidang perikanan, semua santri yang ikut di kewirausahaan semuannya dikumpulkan kemudian setelah itu semua di beri arahan mengenai tata kelola kewirausahaan saya sendri sempat bingung karna saya tidak faham seperti itu, tapi setelah itu ada perkumpulan lagi tapi khusus tidak semuannya hanya kepala bidang saja termasuk saya." Hal ini didukung oleh pendapat Ketua II Bidang Perikanan.“disini cara yangdigunakan untuk merekrut sanrti di bidang kewirausahaan semua di data dan diajak bermusyawaroh, nanti kepala BUMP menjelaskan tentang pengelolaan dan tugas2 tiap bidang." Dapat disimpulkan bahwa tahapan Manajemen Kewirausahaan adalah: 1). Pengauh Memberi arahan Kepada Kepala BUMP, 2). Kepala BUMP menginformasikan mengenai manejemen kewirausahaan. 3). Kepala BUMP mengajak setiap kepala bidang untuk mempraktikannya. 4). Kepala BUMP mengajak kepala bidang untuk mempraktikan manajemen dalam kesehariannya.

b. Alur Manajemen kewirausahaan yang ada di Pondok Pesantren Fathul Ulum Fathul Ulum digambarkan sebagai berikut: 1) Tahap Pertama: Kiai mendelegasikan kewenangan kepada Kepala Bidang Usaha untuk mengelola, menjalankan, serta mengevaluasi kegiatan usaha. 2) TahapKedua: Seluruh pengurusdi bidang masing-masing harus memberikan progresskepadakiai terhadap Kewiraushaan yang akan atau sudah dilakukan. 3) TahapKetiga: Melaksanakan apa yang sudah menjadi program sesuai dengan bidng masing-masing. 4) Tahap keempat: mengontrol pelaksanaan kegiatan kewirausahaan pada masing-masaing bidang. 5) Tahap akhir: melakukan evaluasi disetiap rpat yang telah di sepakati untuk mengetahui hasil dari setiap bidang masing-masing

c. Tahapan Manejemen Kewirausahaan di Pondok Pesantren Fathul Ulum Jombang terbagi manjadi empat tahap yaitu Planing, Organizing. Actuating danControling Hal ini didasarakan pada hasil wawancara, observasi dan dokumentasi oleh peneliti. Pengasuh Pondok Pesantren Fathul Ulum menyatakan.” Manjemen Kewirausahaan yang ada di PP Fathul Ulum itu seperti biasanya, harus ada rencana, kemudian membentuk kepengurusan dan pemimpin untuk menjalankan kewirausahaan yang ada disini stelah itu hasil dari keja mereka dicek"

d. Peningkatan life skill di Pondok Pesantren Fathul Ulum ada beberapa program yang diterapkan disana diantarannya: 1) Mengadakan pelatihan-pelatihan. 2) Mengundang Tutor dari Luar sesuai Life Skill yang dibutuhkan. 3) Mengadakan Rihlah Tahnan. 4) Mengadakan Study banding ke Pondok lain. 5) Mengirim Santri untuk mengikuti program Kewirausahaan 
Hal ini didasarkan pada pernyataan Pengasuh. "Dalam Peningkatan Life skill santri ada beberapa hal yang kami lakukan diantarannya mngadakan pelatihanpelatihan, mengadakan study banding ke pondok-pondok yang maju dibidang kewirausahaan, dan program rutinan yang kami agendakan yaitu program Rihlah. Atau jalan-jalan tapi dengan tujuan mencari ilmu dibidang kewirausahaan dan ini kami rutinkan setiap setahun sekali."

\section{Hasil Penelitian}

\section{Jenis-jenis Kewirausahaan yang ada di Pondok Fathul Ulum}

Kewirausahaan yang peneliti teliti hanya meliputi dua yaitu Perikanan dan peternakan

a. Bidang Peternakan

Usaha bidang peternakan penuh dengan dinamika danpenuh tantangan sehingga perlu penanganan khusus, karena yang dihadapi adalah makhluk hidup yang bergerak dan tentu mempunyai kekhasan masing-masing. Karena itu, perlu kesiapan mental dan ketelatenan dalam pemeliaraan.

Pondok Pesantren Fathul Ulumini membekali santrinya dengan memelihara kambing, ayam, dan bebek. Pondok pesantren menyediakan lahan atau kandang dan pakan. Santri yang bertugas memelihara hewan ternak di pondok pesantren Fathul Ulumini adalah santri putra yang suudah tarbiyyah.

b. Bidang Perikanan

Usaha perikanan adalah salah satu jenis usaha yang dikembangkan dipondok pesantren Fathul Ulum, jenis ikan yang dibudidayakan di pesantren ini adalah ikan patin dan lele. Membudidayakan ikan di Pondok Pesantren Fathul Ulum merupakan kewirausahaan yang berkaitan dengan life skill santri yang praktek langsung di kolam budidaya dengan bimbingan intensif langsung oleh Ustadz. Usaha perikanan ini amat potensial sekali baik yangdi laut maupun didarat.

Hal ini sebagaimana dijelaskan oleh A. Halim dkk. dalam bukunya Manjemen Pesantren menjelaskan bahwa pada umunya seorang kiai sebelum membangun sebuah pesantren telah mandiri secara ekonomi, misalnya sebagai 
petani, pedagang, dan sebagainya. Sehingga ini mengandung arti bahwa kiai telah mempersiapkan dari secara sungguh-sungguh, tidak hanya dari aspek mental, tetapi sosial ekonomi. Jiwa dan dan semangat interpreneusibip inilah yang mendasari kemandirian perekonomian pesantren. ${ }^{8}$

\section{Implementasi Manajemen Kewirausahaan di Pondok Pesantren Fathul} Ulum

a. Proses Manajemen Kewirausahaan di Pondok Pesantren Fathul Ulum.

1) Tahap permulaan Perencanaan (Planing) yaitu pengasuh membuat perencanaan mengenai perekrutan pengelola kewirausahaan.

Tahapan perencanaan Manajemen Kewirausabaan sudah merencanakan Manajemen Kewrausahaan dengan baik. Dari petinggi pondok pesantren yaitu pengasuh PPFU, Kepala BUMP dan pengurusharian sampai dengan devisi-devisinya. Penyusunan perencanaan Manajemen Kewirausahaan di PPFU, Pengasuh dan semua pengurus mengadakan rapat setiap semesteruntuk terlibat mendesain kegiatan-kegiatan kewirausahaan yang dilakukan ke depan selama satu semester. Hal tersebut bertujuan agar kegiatan- kegiatan dapat terprogram dengan baik. Sehingga dapat digunakan sebagai acuan dalam sebuah kegiatan di pesantren. Namun dalam perencanaan yang dilakukan di PPFU ini merupakan perencanaan yang sederhana, karena di dalamnya hanya mempersiapkan kegiatan yang dilakukan selama satu semester saja, tidak membuat rencana yang lebih khusus dan spesifik untu kper kegiatan masing-masing.

Hal ini sebagaimana dijelaskan oleh Muawanah dalam bukunya Manajemen Pesantren Mahasiswa yang dikutip dari bukunya (Buford dan Badein) mengatakan bahwa fungsi manajemen dasar yang harus ada dalam sebuah organisasi atau lembaga yaitu adanya perencanaan, pengorganisasian, penyusunan staf dan pengelolaan sumberdaya

${ }^{8}$ A. Halim, dkk., Manajemen Pesantren, (Pustaka Pesantren:2009), 225 
manusia, pengarahan dan pemberian pengaruh, pengendalian. ${ }^{9}$ Sementara H.B. Siswanto mengatakan dalam bukunya Pengantar Manajemen bahwa fungsi manajemen yaitu ada perencanan, pengendalian, pengorganisasian, pengarahan, pemotivasian, dan pengendalian. ${ }^{10}$

2) Tahapan kedua (Organizing) yaitu Pengasuh dibantu Dewan Pembina mengumpulkan santri yang telah dipilih sesuai kemampuan dalam pengelolaan untuk diberi arahan tentnag manajemen kewirausahaan dan tata kelolannya.

Pengorganisasian merupakan lanjutan dari fungsi Perencanaan dalam sebuah sistem manajemen. Pengorganisasian bisa dikatakan sebagai "uratnadi" bagi seluruh organisasiatau lembaga. Oleh karena itu, pengorganisasian sangat berpengaruh terhadap berlangsungnya suatu organisasi atau lembaga, termasuk di dalamnya lembaga pendidikan.

Pengorganisasian di Pondok pesantren ini cukup baik dan tertata dengan rapi. Pengorganisasian disesuaikan dengan pembidangan para santri, berdasarkan minat santri sendiri. Seperti halnya Pengelolaan Percetakan dan pemasarannya., Bidang ini sesuai dengan minat dari santri sendiri yang berkeinginan untuk belajar mengenai percetakaan yang meliputi, sablon, desain baju dan sebagainya dan yang lain menyesuaikan dari bakatdan minat santri. Dari berbagai kegiatan yang ada santri mampu untuk melaksanakan dengan maksimal sehingga dapat berjalan dengan baik.

Sementara menurut Muawanah megatakan bahwa pengorganisasian adalah suatu proses untuk menentukan pengelompokan dan mengatur secara bersama dalam suatu kegiatan untuk mencapai tujuan, menentukan orang-orang yang akan melakukan aktifitas atau kegiatan, menyediakan alat yang diperlukan, menetapkan wewenang yang dapat dideligasikan kepada setiap individu yang akan melaksanakan aktifitas tersebut. ${ }^{11}$

Begitu juga dengan Pondok Pesantren tersebut Secara umum struktur organisasi di Pondok Pesantren Fathul Ulum terbagi kedalam empat divisi yaitu: divisi Bidang Pendidikan, divisi bidang Humasy, divisi Bidang Sarpras, divisi bidang BUMP, divisi bidang

\footnotetext{
${ }^{9}$ Muawanah, Manajemen Pesantren Mahasiswa, (Jakarta: PT Bumi Aksara, 2017), 23

${ }^{10}$ H.B. Siswanto, Pengantar Manajemen, (Jawa Timur: STAIN Kediri Press, 2009), 36

${ }^{11}$ Muawanah, Manajemen Pesantren Mahasiswa, (Jakarta: PT Bumi Aksara, 2017), 40
} 
pemberdayaan masyarakat, Kemudian dalam memudahkan pengorganisasian di bagian BUMP sendiri membawahi beberapa bidang kewirausahaan sesuai dengan wiraushaan yang ada di Pondok Pesantren Fathul Ulum diantaranya, ada bidang perikanan, bidang peternakan, bidang percetakan, bidang penjahitan, bidang tataboga dan dari devisi sudah tertata tanggung jawab dari per devisi yang ada, sehingga amanah yang diberikan pengasuh sudah diemban santriyang mendapatkantugas dari atasan. Namun semua itu dilihat dari kemampuan setiap individu masing-masing. Dan tidak ada keterpaksaan karena keinginan dari santri itusendiri. Realita untuk menunjang suatu keberhasilan dibutuhkan sebuah tim yang harus bekerja sama, dengan kesatuan yang unggul akan menghasilkan out put yang maksimal. Dandi PPFU santri dan pendidik bekerja sama dengan baik karena pembelajaranyang dilakukan dengan berdiskusi dan tanya jawab langsung dalam satu waktu yaitu santri putra dan santri putri. Oleh karena itu dengan adanya kerjasama yang baik akan menambah hubungan yang baik sehingga terjalin keeratan antara satu dengan yang lainnya.

3)Tahapan Ketiga (Aktuating) yaitu bagian-bagian yang telah disesuaikan dengan keputusan pengasuh, membacakan tata kerja dalam kewirausahaan dan program- yang harus dijalankan dan dikembangkan, setelah itu kepala bidang yang telah terpilih bertugas mengumpulkan anggota santri sesuai data yang terkumpul kemudian membacakan terlebih dahulu sistem manajemen atau tugas-tugas pokok dan program yang harus dijalankan, setelah selesai santri diberi kesempatan untuk menanyakan hal-hal yang belum jelas mengenai sistm manajemen kewirausahan.

Fungsi penggerakan dalam manajemen mencakup di dalamnya adalah kepemimpinan, motivasi, komunikasi, dan bentuk-bentuk lain dalam rangka memengaruhi seseorang untuk melakukan sesuatu guna mencapai tujuan organisasi. Kepemimpinan berfungsi sebagai pemberi arahan komandan pember iserta pengambil keputusan organisasi. Motivasi berguna sebagai cara untuk menggerakkan agar tujuan organisasi tercapai. Sedangkan, komunikasi berfungsi sebagai alat untuk menjalin hubungan dalam rangka fungsi penggerakan dalam organisasi. Secara umum proses pelaksanaan Manajemen lifes skill dapat terlaksana dengan baik, maka dapat dilihat dari Manajemen lifes kill yang diberikan dari pengasuh ke pada kepala BUMP, kemudain disampaikan kepada seluruh bidang-bidang, anggota yang ikut didalamnya, sehingga semua kalangangan yang terlibat tahu persis tentang alur organisasai yang ada tidak hanya sekedar menjadi anggota saja yang tidak mngetahui apapun yang hanya patuh kepada atasan bukan aatas dasar manajemen tapi atas dasar takut dan sebagainya, dengan demikian mereka 
siap dijadikan sebagi orang-orang hebat yang tidak hanya memiliki kemampuan dibidang life skill yang mereka miliki jga mampu embuat manajemen yang bagus dan efektif, dan juga kelak mereka akan menjadi seoranng santri yang kokoh untuk memberikan bekaldalam menghadapi masayangakan datang.

Hal ini Muawanah ${ }^{12}$ menegaskan bahwa dalam pengelolaan di pondok pesantren usnsur-unsur yang ada di dalanya harus memahami tugas, wewenang dan tanggung jawabnya masing-masing, maka perlu dilakukan aktifitas untuk menggerakkan, yaitu bagamimana orang-orang yang telah terlibat dalam organisasi itu digerakkan untuk melaksanakan aktifitasnya.

4) Tahap keempat (Controling), yaitu Pengasuh dibantu dewan Pembina Mengontrol hal-hal yang berkaitan dengan paparan diatas, seperti mengawasi alur manajemen dan koordinasi dari setiap anggota, Tahap trakhir adalah Evalusi. Disini semua pengelola dikumpulkan menjadi satu dan dipaparkan semua kejadian baik yang sesuai dengan alur organisasi atau yang berlainan dalam kata lain masalah yang di temukan dilapangan saat pengasuh melakukan controlling. Evaluasi di Pondok Fathul Ulum ini belum dirumuskan dengan baik, tetapi pesantren ini hanya menggunakan sistem evaluasi dengan pengungkapan secara langsung. Akan tetapi belum mempunyai standar nilai dalam proses evaluasi.

Maka dalam evaluasi yang dilakukan di Pondok Fathul Ulum masih tergolong manual atau tradisional, karena hanya pengungkapan saja yang dilakukan untuk proses pengevaluasian kegiatan life skill santri di bidang masing-masng yang sudah terlaksana.

b. Proses Meningkatkan Life Skill santri di Pondok Fathul Ulum.

Pengembangan dan peningkatan lifes kill di pondok pesantren harus disesuaikan dengan kebutuhan dan minat bakat santri. Jika tidak, maka santri tidak akan mempunyai motivasi ikut serta melaksanakan pendidikan life skill. Agar hal tersebut tidak terjadi penyelenggaraannya harus dengan cara selektif seperti:

${ }^{12}$ Muawanah, Manajemen Pesantren Mahasiswa...45 
a) Tidak semua jenis program kegiatan pendidikan ketrampilan dan kejuruan diselenggarakan oleh pondok pesantren, kecuali pondok pesantren yang ditetapkan untuk tempat latihan regional.

b) Tidak semua santri mengikuti setiap jenis ketrampilan kejuruan yang diselenggarakan di pondok pesantren. Namun hanya didasarkan atas dasar kemauan, minat, bakat serta fasilitas yang tersedia di pondok pesantren.

Penyelenggaraan ketrampilan di pondok pesantren diusahakan tidak terbentur dengan penyelenggaraan kegiatan pendidikan yang diprogramkan pondok pesantren, agar santri yang terjun dalam pengembangan lifes kill tidak merasa tertanggu dan saling mengimbangi. Berbagai lifes kill yang dikembangkan dipondok pesantren merupakan kebutuhan santri sebagai modal manusia yang mempunyai semangat wirausaha sekaligus untuk menunjang pembangunan lingkungan masyarakat.

Pengenalan lifes kill di pondok pesantren dalam berbagai bidang ketrampilan dan usaha pemberdayaan masyarakat yang menguntungkan dapat dimulai dengan cara sebagai berikut. Peningkatan life skill santri di Pondok Fathul Ulum juga menyesuaikan kebutuhan dan minat santri sehingga santri bisa memilih sesuai dengan keinginnnya dalam, begitupun dalam pelaksanaan kegiatan juga dilakukan diluar kegiatan mengaji, artinya santri tidak merasa rugi dalam menjalankan program life skill yang diberikan pondok karena waktu yang diberikan tidak berbenturan dengn kegiatan pokok seperti mengaji, dalam penigkatan life skill santri di Pondok Fathul Ulum selain dengan hal diatas ditambah dengan program-program lain diantaranya. a). Mengikuti pelatihan sesuai dengan bidang masing-masing, b). Mengadakan rihlah ke antar pondok yang memiliki wirausahaa atau life skill yang berkembang, c). Mengadakan studi banding ke pondok lain, f). Mengirim delegasi dalam bidang life skill yang ada di Pondok Pesantren Fathul Ulum.

\section{Kesimpulan}

Dari pembahasan dan penelitian yang peneliti paparkan penulis dapat mengambil kesimpulan sebagai berikut: Pertama, Bentuk Wirausaha yang ada di Pondok Pesantren Fathul Ulum Diwek Jombang: a). Bidang Tata Boga, b). Bidang Perternakan, c). Bidang Perikanan, d). Bidang Percetakan, e).Bidang Penjahitan. Proses 
implementasi manajemen kewirausahaan dalam meningkatkan life skill santri yang ada di Pondok Pesantren Fathul Ulum Diwek Jombang yaitu: (a) Perencanaan/planning yiatu pengasuh bertugas memberikan arahan kepada pengurus atau santrinya tentang tujuan, fungsi dan langkah-langkah yang harus dilakukan sebelum membuat kewirausahaan yang ada di pondok Pesantren Fathul Ulum Jombang. Kemudian dengan arahan tersebut tersusunlah bebara-bebrapa aspek yang disepakati. (b) pengorganisasian/organizing yaitu pengasuh juga membuat struktural kepengurusan sesuai dengan perencanaan misalnya terkait dengan kpengurusan Bidang tata boga, peternakan, perikanan, percetakan dan penjahitan. (c)Pelaksanaan/Actuating yaitu setiap kepala bidang menjalankan Proker (Program Kerja) yang telah dibentuk. Kemudian pengasuh memberikan pembinaan life skill kepada para santri khususnnya santri Ulya. Sesuai dengan waktu yang telah ditentukan. (d) Pengawasan (controlling) yaitu pengasuh mengadakan evaluasi terhadap apa yg telah dilakukan sesuai dengan perencanan guna untuk mengetahui tingkat pencapaian tarjet dan tujuan yang sudah disepakati dalam proses perencaan. Eveluasi ini dilakukan pada seluruh bidang life skill dengan waktu yang sudah menjadi ketentuan bagi pengasuh.

\section{Daftar Rujukan}

Ali. Mohammad, Strategi Penelitian Pendidikan. Bandung: Angkasa, 1993.

Departemen Agama RI, Pondok Pesantren dan Madrasah Diniyah, Pertumbuban dan Perkembangannya, Jakarta: Ditjen Kelembagaan Agama Islam Departemen Agama RI, 2005.

Drajat. Zakiah, Ilmu Pendidikan Islam, Jakarta: Bumi Aksara. 2013.

H.B. Siswanto, Pengantar Manajemen, Jawa Timur: STAIN Kediri Press, 2009.

Halim. A., dkk., Manajemen Pesantren, Pustaka Pesantren: 2009

Muawanah, Manajemen Pesantren Mahasiswa, Jakarta: PT Bumi Aksara, 2017.

Mujib. Abdul, Ilmu Pendidikan Islam, Jakarta: Kencana Prenada Media, 2006.

Samani. Muchlas, Kecakapan Hidup Melalui Pendekatan Pendidikan Berbasis Luas, (Team Broad Based Education LPM Unesa.Surabaya: Swa Bina Qualita Indonesia, 2008.

Slamet, Pendidikan Kecakapan Hidup; Konsep Dasar, Jurnal Pendidikan dan Kebudayaan no. 037 tahun VIII Juli 2002.

Usman. Moh. Uzer, Menjadi Guru Profesional, Bandung: PT Remaja Rosdakarya, 2008. 